\title{
Pericardial adhesions and cardiac surgeons' nightmares
}

\author{
Victor A. Ferraris, MD, $\mathrm{PhD}$
}

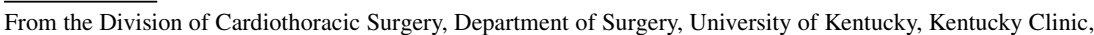 \\ Lexington, Ky. \\ Disclosures: Author has nothing to disclose with regard to commercial support. \\ Received for publication April 9, 2018; accepted for publication April 9, 2018; available ahead of print May 2, \\ 2018. \\ Address for reprints: Victor A. Ferraris, MD, PhD, Division of Cardiothoracic Surgery, Department of Surgery, \\ University of Kentucky, A301 Kentucky Clinic, 740 S Limestone, Lexington, KY 40536-0284 (E-mail: \\ ferraris@uky.edu). \\ J Thorac Cardiovasc Surg 2018;156:1609-10 \\ $0022-5223 / \$ 36.00$ \\ Copyright (c) 2018 by The American Association for Thoracic Surgery \\ https://doi.org/10.1016/j.jtcvs.2018.04.035
}

Nothing stirs up bad memories for cardiac surgeons like redo operations that are complicated by sternal reentry problems. These problems happen around $10 \%$ of the time in redo cardiac procedures. ${ }^{1}$ Many of these problems revolve around pericardial adhesions, and the list of interventions aimed at reducing pericardial adhesions is legion. Synthetic materials (treated bovine pericardium, polytetrafluoroethylene patches, etc) to cover the heart after initial operation were probably the first things used to facilitate sternal reentry, only to be followed by notes of caution. ${ }^{2,3}$ All sorts of chemicals, natural products, and synthetic or autologous tissues have been offered up as initial operative alternatives to facilitate sternal reentry. Modalities as disparate as autologous pericardial flaps, ${ }^{4}$ alcohol consumption, ${ }^{5}$ instillation of various drugs into the pericardium at sternal closure, ${ }^{6}$ nanostructured synthetic films impregnated with steroids, ${ }^{7}$ acellular tissue impregnated with angiogenic agents, ${ }^{8}$ and temperaturesensitive polymer films ${ }^{9}$ have all been suggested as means of limiting pericardial adhesions and facilitating sternal reentry. Perhaps the large number of putative remedies to facilitate sternal reentry is the best evidence that there are no good solutions to limit adhesions and reduce the risks associated with sternal reentry. The missing piece in most of these studies is an examination of the molecular components of postoperative adhesion formation and identification of molecular targets that could reduce these adhesions.

The article by Fedak and coauthors ${ }^{10}$ in this issue of the Journal presents an analysis of the impact of a mucinlike glycoprotein, glycoprotein 4 (PRG4), on pericardial adhesion formation. Fedak and coauthors ${ }^{10}$ characterized PRG4 expression in human pericardium and examined its effects both in vitro on human myofibroblast activity and in vivo on adhesion formation in a pig model. The importance of this research revolves around myofibroblasts, because these cells can secrete collagen and initiate the progression to adhesion formation. ${ }^{11}$ The experiments of Fedak and coauthors ${ }^{10}$ suggest that the loss of PRG4 in pericardial fluid can trigger pericardial adhesion formation, a condition

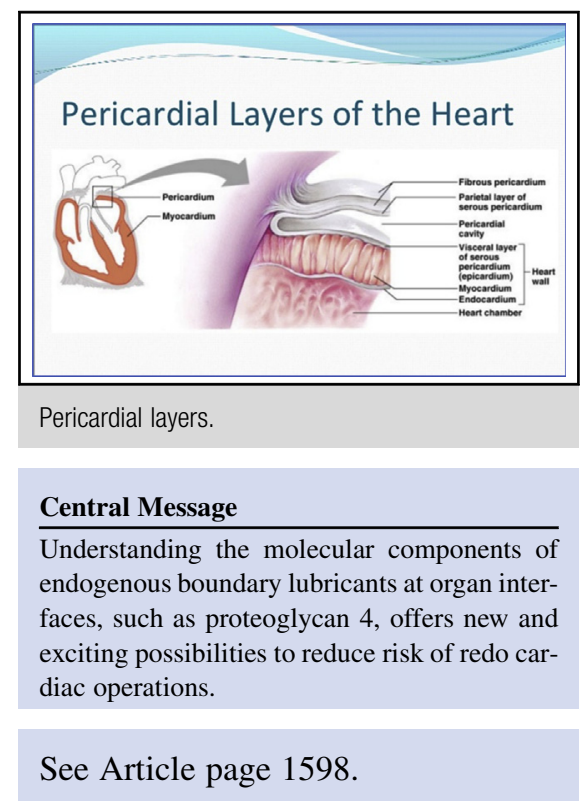

that depends on myofibroblast activation. Perhaps the most intriguing aspect of the article by Fedak and coauthors ${ }^{10}$ is the finding that restoration of PRG4 into pericardial fluid may prevent adhesion formation. They found that PRG4 is expressed by human pericardial mesothelial cells. Recombinant human PRG4 prevented cardiac myofibroblast attachment to pericardium and limited myofibroblast activity. In particular, their in vivo model identified PRG4-associated attenuation of collagen formation from myofibroblast cells. The experiments of Fedak and coworkers ${ }^{10}$ have enormous implications for redo cardiac operations. The fact that they considered molecular and biochemical components of pericardial function sets their work apart from most other published putative solutions to limit pericardial adhesions.

PRG4 (or lubricin) is a proteoglycan that is encoded by the PRG4 gene. It acts as a boundary lubricant and was first isolated in articular cartilage. The same group writing here as Fedak and coauthors ${ }^{10}$ was one of the first groups to identify and isolate PRG4 in pericardial fluid and to identify its role in limiting pericardial adhesions. ${ }^{12}$ Because of their early work, ${ }^{11}$ Fedak and coauthors ${ }^{10}$ hypothesize that PRG4 is an important component of myocardial adhesion attachment of the heart to the parietal pericardium. There are many details of this interaction that remain to be worked out. The exact target of PRG4 is uncertain. It is likely that PRG4 interacts with myofibroblasts in some way, and the nature of this interaction likely involves receptors on target 
cells. Discovering the exact nature of the cellular target for PRG4 is a logical next step for this group. There are intriguing possibilities that include the use of knockout mice (https://www.jax.org/strain/025737) and studies of patients with inherited absence of the PRG4 gene (http://www. genecards.org/cgi-bin/carddisp.pl?gene=PRG4). There may be other molecular approaches to preservation of mesothelial cells and limitation of adhesions, so more work needs to be done. Nonetheless, this work of Fedak and coauthors ${ }^{10}$ advances the process of dissecting the molecular components of pericardial adhesion formation. The results of this ongoing work could provide patients with safer redo cardiac operations and mean less misery for cardiac surgeons who must deal with these difficult, high-risk procedures.

\section{References}

1. Imran Hamid U, Digney R, Soo L, Leung S, Graham AN. Incidence and outcome of re-entry injury in redo cardiac surgery: benefits of preoperative planning. Eur $J$ Cardiothorac Surg. 2015;47:819-23.

2. Heydorn WH, Ferraris VA, Berry WR. Pericardial substitutes: a survey. Ann Thorac Surg. 1988;46:567-9.

3. Mathisen SR, Wu HD, Sauvage LR, Walker MW. Prevention of retrosternal adhesions after pericardiotomy. J Thorac Cardiovasc Surg. 1986;92:92-8.
4. Klingman RR, Berry WR, Ferraris VA. Pericardial flap and resternotomy injury. Ann Thorac Surg. 1993;56:204.

5. Lassaletta AD, Chu LM, Sellke FW. Effects of alcohol on pericardial adhesion formation in hypercholesterolemic swine. J Thorac Cardiovasc Surg. 2012; 143:953-9.

6. de Oliveira PP, Bavaresco VP, Silveira-Filho LM, Schenka AA, Vilarinho KA, Barbosa de Oliveira Severino ES, et al. Use of a novel polyvinyl alcohol membrane as a pericardial substitute reduces adhesion formation and inflammatory response after cardiac reoperation. J Thorac Cardiovasc Surg. 2014;147: 1405-10.

7. Robinson E, Kaushal S, Alaboson J, Sharma S, Belagodu A, Watkins C, et al. Combinatorial release of dexamethasone and amiodarone from a nanostructured parylene-C film to reduce perioperative inflammation and atrial fibrillation. Nanoscale. 2016;8:4267-75.

8. Chang Y, Lai PH, Wang CC, Chen SC, Chang WC, Sung HW. Mesothelium regeneration on acellular bovine pericardia loaded with an angiogenic agent (ginsenoside $\operatorname{Rg} 1$ ) successfully reduces postsurgical pericardial adhesions. J Thorac Cardiovasc Surg. 2006;132:867-74.

9. Kang H, Chung YS, Kim SW, Choi GJ, Kim BG, Park SW, et al. Effect of temperature-sensitive poloxamer solution/gel material on pericardial adhesion prevention: supine rabbit model study mimicking cardiac surgery. PLoS One. 2015; 10:e0143359.

10. Park DSJ, Regmi SC, Svystonyuk DA, Teng G, Belke D, Turnbull J, et al. Human pericardial proteoglycan 4 (lubricin): Implications for postcardiotomy intrathoracic adhesion formation. J Thorac Cardiovasc Surg. 2018;156:1598-608.

11. Hinz B, Phan SH, Thannickal VJ, Galli A, Bochaton-Piallat ML, Gabbiani G. The myofibroblast: one function, multiple origins. Am J Pathol. 2007;170:1807-16.

12. Park D, Regmi S, Svystonyuk D, Belke D, Teng G, Mewhort H, et al. Expression and role of lubricin in the human pericardium: implications as a therapeutic to prevent post-operative adhesions. Can J Cardiol. 2016;32(Suppl 1):S226-7. 